\title{
Jörgen Lundälv
}

\section{Välfärden, samhällskritiken och medierna}

\section{- socialarbetares röster i podcaster i socialpolitik och socialt arbete}

Welfare, critique and the media - social workers' voices in podcasts in social policy and social work

Social workers and social policy researchers can engage in social work and critical social policy, in traditional media and in the new media. In recent years, the social media have been increasing in both the international media systems and in the media system in Sweden. One channel for social workers to use to be able to make their voice heard in society is to participate, debate and discuss social policy in podcasts. In 2016, the Union for Professionals, Akademikerförbundet SSR, developed "Social Services Podcasts". At the same time the National Board of Health and Welfare introduce a new podcast on social services and health care that is called "Podcast in the Deep". This article examines voices and themes in social policy and social work in a total of 112 programmes in two podcasts: "Socialtjänstpodden" and "In Depth" during the years 2016-2019. There are several challenges for the storytelling tradition and social criticism in social policy and social work in podcasts, which is highlighted in this article.

Jörgen Lundälv är docent i socialt arbete och verksam vid Institutionen för socialt arbete, Göteborgs universitet.

Kontakt: jorgen.lundalv@socwork.gu.se 


\section{Introduktion}

I takt med samhällsförändringar och tider då det ställs allt högre krav på socialt arbete och socialarbetaren i välfärdssamhället är det nödvändigt att diskutera om samhällskritikens roll i både professionen och i politiken. Som socialarbetare finns det all anledning att betrakta den historiska utvecklingen och bland annat se vad som hänt med frågor som fattigdom, utsatta grupper och hur socialarbetare positionerat sig i kampen för bättre levnadsvillkor, livsvillkor och en förstärkt socialpolitik (Swärd, 2017; Swärd \& Edebalk, 2017; Swärd, 2018).

Socialt arbete och socialpolitik har genom tiderna på olika vis artikulerats och rapporterats i media. Det har handlat om press, radio och tv. Betydelsen av att synliggöra socialt arbete och socialpolitik i både pressens nyhetsrapportering och inom samhällskritik och opinionsbildning har kommit till uttryck inom forskningen (Lundälv, 2018). Klassiskt har varit att studera medierapporteringen i traditionella medier (press, radio och tv). Under senare år har emellertid aktualiteten och spridningen av nyheter och opinionsyttringar kommit att ske allt mer i de sociala medierna. Det har benämnts spridbar media (Jenkins, Ford \& Green, 2014). Mätningar visar att sju av tio medborgare i de nordiska länderna dagligen lyssnar på radio, bland annat via internet. Däremot har antalet podcast-lyssnare varit relativt få. Studien visade att 12 procent av invånarna i Sverige lyssnade på webb/poddradio under en vecka år 2016. Högst var lyssnandet $i$ åldersgruppen 25-44 år (Nordicom, 2017). Samtidigt har podcaster i de sociala medierna blivit allt mer populära. Ett exempel på det är att podcaster i socialpolitik och socialt arbete också används vid flera universitet på den internationella arenan. Professor emerita Fiona Williams vid University of Leeds föreläser vid University of Oxford om socialpolitik ("What next for social policy") i en videopodcast (https://podcasts.ox.ac.uk/what-next-social-policy) (Williams, 2018). Den spelades in den 9 november 2018 vid University of Oxford och är tillgänglig för alla att lyssna på via de sociala medierna. Precis som vi kan läsa om Fiona Williams förklaringar och tolkningar av socialpolitik i hennes texter, lika enkelt kan vi lyssna till hennes reflektioner och socialhistoriska beskrivningar vid anförandet (Williams, 1989, Oakley, Popay \& Williams, 1999; Williams, 1999; Williams, 2016). Podcaster gör att vi kan lyssna till inlägg och förklaringar till ämnet socialpolitik som inte har varit möjligt tidigare. Radiomediet har i Sverige varit föremål för diskussion om yttrandefrihet, kontroversiella ämnen i Sveriges radio och Säpos övervakning av medarbetare inom radiomediet (Elgemyr, 2005).

Socialarbetarens röst i samhällsdebatten är viktig och det finns flera kanaler och tillvägagångssätt som en socialsekreterare kan använda sig av för att vara aktiv i samhällsarbete i form av opinionsbildning och medierapportering. I den här artikeln är initiativtagarna till podcaster två olika aktörer inom socialt arbete 
och socialpolitik. Den första aktören är professionsförbundet för socialt arbete Akademikerförbundet SSR som bildade en podcast med namnet Socialtjänstpodden. Den får ses som en så kallad professionspodd. Samtidigt valde också en myndighet med ansvar för socialtjänsten i Sverige - Socialstyrelsen - att bilda en podcast med namnet $P a ̊$ djupet - en podd från Socialstyrelsen. Företrädarna för de båda podcasterna, som publiceras på internet, kan visserligen helt själva sätta agendan för innehåll och fokus i frågor om socialt arbete och socialpolitik och bjuda in gäster till programmen. Men i de båda podcasterna handlar det också om att låta exempelvis socialarbetare, företrädare från socialt arbete och socialpolitik, samverkanspartners och forskare komma med förslag och idéer på både programinnehåll och fokus. På så vis kan de båda podcaster som studeras i artikeln ses som plattformar för demokratiska samtal och debatter om det sociala arbetets innehåll och praktik samt socialpolitikens utformning och inriktning. Nya platser för att diskutera brännande socialpolitiska frågor har uppstått.

\section{Syfte och frågeställningar}

Det saknas i dag kunskap om vilka problem och debattämnen som socialarbetare medvetet valt att lyfta upp i samhällsdebatten i den offentliga sfären och huruvida de själva är aktiva i en sådan debatt, särskilt i radioprogram på internet som benämns podcaster. Forskningsproblemet som fokuseras i artikeln handlar om vilka socialpolitiska problem och debattämnen som socialarbetare lyft upp i podcaster som publicerats på internet. Den här studien är viktig eftersom socialarbetare vid inspelning och publicering av dem inte möter yrkesverksamma journalister som de annars gör i den traditionella medierapporteringen. Där kan de visa en stor osäkerhet och till och med rädsla för journalisterna. I stället möter de nu andra professionsföreträdare och programledare som inte är journalister men som leder inspelning och produktion av podcaster. Det är också fråga om ett innehåll som inte blir föremål för redigering på samma sätt som ett radioinslag eller en nyhetsartikel som produceras av en journalist vid en radiostation eller dagstidning. Syftet med studien är att undersöka i vilken utsträckning som socialarbetare får sina röster hörda i podcaster i Sverige och vilka debattämnen inom ämnena socialpolitik och socialt arbete som de deltagit i. Det kunskapsbidrag som artikeln ger, handlar med andra ord om vilka möjligheter som podcaster inom professionen skapar som ett komplement till annan medierapportering i samhället. Tre frågor undersöks i artikeln: 1) I vilken utsträckning har socialarbetare fătt sin röst hörd i olika diskussioner om socialt arbete och socialpolitik i Socialtjänstpodden respektive På djupet - en podd från Socialstyrelsen? 2) Vilka teman har socialarbetare lyft upp i dem? 3) Vilka är de andra professionerna och deltagarna som medverkat i de 
olika avsnitt som producerats? Genom att studien särskilt fokuserar på hur socialarbetare deltar i samhällsdebatten i podcaster, finns det goda möjligheter att få ökad kunskap om hur de talar och vad de särskilt lyfter upp och betonar för i första hand kollegor inom den egna professionen men också för andra som kan tänkas ha intresse för socialpolitiska frågor och socialt arbete i samhället.

Det finns flera motiv till att det kan vara både utvecklande och lärande att producera podcaster och lyssna till ljudinslag i de sociala medierna. Därigenom kan det demokratiska samtalet ytterligare vitaliseras genom att olika aktörer inom socialt arbete och socialpolitik ges möjlighet att diskutera och debattera olika sociala frågor. Att delta i en podcast kan också innebära att det finns goda möjligheter att sprida både viktiga frågor, nytt behandlingsarbete, ny forskning och diskussion om policyförändringar.

\section{Disposition}

I avsnittet "Tidigare forskning" presenterar jag relevant forskning om relationen mellan socialt arbete, socialpolitik och samhällskritik genom opinionsbildning. Forskning om att använda podcaster för att kommunicera sociala frågor gås igenom. Artikelns kunskapsbidrag relaterat till tidigare forskning är att studien utgör ett nytt kunskapsfält där socialarbetare kan föra fram debattfrågor och inlägg i podcaster utan att bli utsatta för stress från journalister eller bortvalda (begränsade) på grund av en allt starkare medielogik i samhället där vissa frågor ges mer utrymme än andra.

\section{Tidigare forskning}

Forskning om mediers betydelse, mediesystem och mediehistorik har varit föremål för många studier genom åren. Det har skett samtidigt som samhälleliga förändringar, modernitet och livsvillkor för människor förändrats och rummen för samhällskritik och opinionsbildning kommit att förändras (Thompson, 2001; Strömbäck, 2009; Lundälv \& Lindqvist, 2013; Weibull \& Wadbring, 2014). Både hur medborgare och politiker använder medierna och särskilt de sociala medierna, har blivit allt mer populärt för forskare att uppmärksamma (Williams et al., 2012; Fjellman, Gustafsson \& Rosén Sundström, 2018; Lie Paulsen, 2018; Plantin \& Punathambekar, 2018). I Sverige har forskning om socialt arbete och socialpolitik i medierna uppmärksammats vad avser både medierapportering och socialarbetares aktiva deltagande i samhällsdebatten (Blomberg, 2004; Lundälv, 2018; Sjöström \& Öhman, 2018; Lundälv, 2019). Studier av hur man använder sociala medier både i Sverige och internationellt har visat på potentialer (Lundälv, 2015; Goldkind, Wolf \& Freddolino, 2018; Baum \& Potter, 2019). Likaså har studier genomförts om socialarbetares nätverksaktiviteter och protester i sociala medier (Scaramuzzino 
\& Meeuwisse, 2019). Även mediestrategier inom socialtjänsten har fokuserats (Enbom, Sjöström \& Öhman, 2014). Det finns flera sätt på vilka socialarbetare kan kommunicera sociala frågor till allmänheten. En studie av podcaster i socialt arbete visade att fenomenet inte är så beforskat (Fronek et al., 2016). Studien visade att podcaster har stora potentialer i socialt arbete för att kunna stärka utbildningen och det sociala arbetets identitet samt dess relation mellan teori, forskning och praktik. Studenter i socialt arbete var positiva till att använda podcaster $i$ utbildningen. Över 70 procent ansåg att de bidrog till att öka förväntningarna om den framtida professionsrollen. Även andra studier om att använda podcaster har genomförts (Cartney, 2013; Nyman \& Senneryd, 2015; Gnaur \& Huttel, 2016). De båda forskarna Dorina Gnaur och Hans Huttel ger följande definition av begreppet podcast. De skriver: "The word itself is an amalgam of iPod and broadcast. Nowadays, the term is used to describe any type of recorded audio or video content made accessible to a larger audience and stored on personal or portable devices for (offline) discretionary use" (Gnaur \& Huttel, 2016, s. 6).

Tiitinen (2019) har undersökt socialarbetares användande av yttrandefrihet och media advocacy. Hon har studerat spänningsfältet mellan offentlig kommunikation och det strukturella sociala arbetet samt vilka maktkamper som sker. Tiitinen har också studerat vad som utmärker det strukturella sociala arbetet som kommuniceras i medierna och vilka orsakerna är till att socialarbetare väljer att vara passiva i media. När socialarbetarna förblir passiva bibehålls tystnadskulturen. Sammanfattningsvis är forskningen begränsad. Forskningen har fokuserat på nyhetsrapportering, opinionsbildning och tryckt press samt dess behandling av socialt arbete och socialpolitik. Däremot finns det fler studier om hur yrkesverksamma socialarbetare kan bryta tystnaden i samhället genom att använda både sin yttrandefrihet och de sociala medierna för att nå ut med debattfrågor (Scaramuzzino \& Meeuwisse, 2019; Tiitinen, 2019). Samtidigt visar en nationell webbenkätstudie att relativt få socialarbetare använder de traditionella medierna för att till exempel få en opinionsartikel publicerad (Lundälv, 2019).

\section{Teoretiska utgångspunkter}

Studien tar sin utgångspunkt i begreppen agenda-setting ('agendasättande') och tyst kunskap och vilken betydelse de kan tänkas ha för socialarbetarnas benägenhet att delta i socialpolitiska debatter. Begreppet agenda-setting har diskuterats i litteraturen utifrån att aktörer kan ta ett eget initiativ och påverka samt medverka i olika medier, men även att det finns en agendasättande journalistik (McCombs \& Shaw, 1972; Golding \& Middleton, 1982). Den samhällsvetenskapliga teori som forskarna Max McCombs och Donald Shaw utvecklade beskriver den agendasätt- 
ning som sker i medierna genom att medierna skapar konstruktioner av verkligheten (nyheter). Genom att rapporteringen är koncentrerad på ett fåtal ämnen medför det att allmänheten kommer att uppfatta ämnesvalen som de mest angelägna ämnena. Här finns en tydlig koppling till socialpolitiken, nämligen att socialarbetare har ett samhällsuppdrag att medverka i samhällsplanering och delta i den offentliga debatten och kommentera socialpolitiska frågor. Man skulle kunna tala om att det finns ett agendasättande för socialarbetare att lyfta brännande socialpolitiska frågor till en offentlig agenda för debatt. Eftersom socialarbetare har både kunskap och erfarenheter av socialt arbete och socialpolitik i teori och praktik har de goda möjligheter att på ett trovärdigt sätt argumentera, kommentera och påverka samhällsutvecklingen. Socialarbetarna skulle därmed kunna vara med och sätta agendan för sociala och socialpolitiska frågor i den övergripande debatten. I samhällsdebatten finns det socialarbetare som blivit tysta och några har resignerat i stället för att föra en ökad kamp för erkännande. Filosofen Michael Polanyi beskriver "den tysta dimensionen" och menar att det i alla professioner finns en tyst kunskap om problem och fenomen som inte alltid uttalas och berättas om (Polanyi, 2013). Grundtanken i Polanyis filosofi om den tysta dimensionen, det vill säga om den tysta kunskapens innehåll är därför: "Vi kan veta mer än vi kan säga" (Polanyi, 2013, s. 27). För socialarbetare kan den tysta dimensionen vara en stor utmaning eftersom de har stora potentialer att både medverka och utveckla det offentliga samtalet och debatten om socialt arbete och socialpolitik. Fokus i den här artikeln ligger på den muntliga debatten om socialt arbete och socialpolitik. Socialarbetare som sätter agendan och argumenterar för en intervention på samhällsnivå kan använda sig av den egna tysta kunskapen tillsammans med annan kunskap, exempelvis undersökningar och forskning på området. Socialarbetaren som deltar i en podcast har själv makt att avgöra vilka frågor som han eller hon vill delta i, men också hur mycket av den egna förförståelsen och den tysta kunskapen som lyfts fram.

\section{Metod och material}

I Sverige har olika professionsförbund, brukarorganisationer och statliga myndigheter börjat producera podcaster på internet. Exempel på sådana finns i tabell 1 . 
Tabell 1. Översikt över exempel på podcaster vid professionsorganisationer, brukarorganisationer och myndigheter i Sverige.

\begin{tabular}{|c|c|c|}
\hline Organisation eller myndighet & Namn på Podcasts & Bildades år \\
\hline Akademikerförbundet SSR & Socialtjänstpodden & 2016 \\
\hline Akademikerförbundet SSR & Samhällsvetarpodden & 2016 \\
\hline Akademikerförbundet SSR & Chefspodden & 2017 \\
\hline Arbetsförmedlingen & Jobbpodd & 2016 \\
\hline Arbetsgivarverket & Arbetsgivarpodden & 2017 \\
\hline Brottsförebyggande rådet & Snacka om brott & 2015 \\
\hline Habilitering \& Hälsa & $\begin{array}{l}\text { Funka olika - podden om livet med } \\
\text { funktionsnedsättning }\end{array}$ & 2016 \\
\hline $\begin{array}{l}\text { Myndigheten för samhällsskydd } \\
\text { och beredskap }\end{array}$ & Om krisen kommer & 2014 \\
\hline Neuro (Neuroförbundet) & Neuropodden & 2017 \\
\hline Skolverket & S-podden & 2016 \\
\hline Socialstyrelsen & På djupet - en podd från Socialstyrelsen & 2016 \\
\hline Specialpedagogiska skolmyndigheten & Podden Lika värde & 2019 \\
\hline Statistiska Centralbyrån & På tal om siffror & 2019 \\
\hline Strålsäkerhetsmyndigheten & Strålsäkert & 2019 \\
\hline Sveriges Domstolar & Domstolspodden & 2017 \\
\hline Sveriges Kommuner och Landsting & $\begin{array}{l}\text { Demokratiresan - en podcast om } \\
\text { demokrati }\end{array}$ & 2019 \\
\hline Synskadades Riksförbund & Radio SRF & 2014 \\
\hline Vårdförbundet & Vårdförbundets podd & 2016 \\
\hline Utrikesdepartementet & UD-podden & 2017 \\
\hline
\end{tabular}

Det empiriska materialet består av podcaster i socialpolitik och socialt arbete $\mathrm{i}$ Sverige och som producerats och publicerats på internet under perioden 20162019. De två podcaster ("poddar") som har undersökts är Socialtjänstpodden (Akademikerförbundet SSR) (https://poddtoppen.se/podcast/1176054131/socialtjanstpodden) och På djupet - en podd från Socialstyrelsen (http://www.socialstyrelsen.se/padjupet-podd/Files/index.html).

Urvalet av dem har gjorts utifrån kriteriet att den ena podcasten representerar professionen socialt arbete (Socialtjänstpodden) medan den andra (På djupet - en 
podd från Socialstyrelsen) representerar myndigheten Socialstyrelsen och dess båda ansvarsområden som fokuserar på hälso- och sjukvård samt socialtjänst. De två podcasterna har olika karaktärer. Socialtjänstpodden fokuserar på socialpolitik, socialt arbete och professionsfrågor och produceras av Akademikerförbundet SSR medan den andra är en typ av "myndighetspodd" med Socialstyrelsen som ansvarig utgivare. Det som förenar dem båda är att de behandlar socialt arbete och socialpolitik. De ger samlat en kompletterande och alternativ bild till medierapporteringen eftersom både socialarbetare, samverkanspartners och forskare medverkar och fokuserar på olika perspektiv. Socialstyrelsen beskriver sin podcast på följande vis: "I vår podd djupdyker vi i olika frågor med koppling till socialtjänst och hälso- och sjukvård. Det kan handla om fallolyckor, legitimationer, patientsäkerhet, organdonation, psykisk ohälsa, krishantering, välfärdsteknik, barns rättigheter och mycket, mycket mer"

(https://podcasts.apple.com/se/podcast/p-c3-a5-djupet-en-podd-fr-c3-a5nsocialstyrelsen/id1 161759894?mt=2\# episodeGuid=9ed62007bf444ff08aed2fa9 ed83able). Akademikerförbundet SSR beskriver Socialtjänstpodden på följande vis: "Podden för dig som är intresserad av socialt arbete och socialpolitik. Varannan vecka tar Josefine Johansson, professionsstrateg på förbundet, upp aktuella ämnen för socialtjänsten, ibland tillsammans med en gäst" (https://akademssr.se/opinion/ vara-podcasts/socialtjanstpodden).

Ett totalurval har gjorts i undersökningen. Det innebär att samtliga producerade och publicerade avsnitt i de båda podcasterna ingår i det empiriska materialet. Undersökningsmaterialet består av totalt 112 avsnitt som producerades och sändes under totalt 30 månader - perioden 4 oktober 2016 till 17 april 2019. Både en kvantitativ och en kvalitativ innehållsanalys har använts vid analysen av det empiriska materialet (Krippendorff, 2019). Ljudinslagen varierar i längd från 17 minuter till det längsta inslaget som omfattar 48 minuter. Språket i samtliga programinslag har varit svenska. Samtliga podcastinslag har genomlyssnats. Samtliga påannonseringar (ingresser) till alla 112 avsnitten i de båda podcasterna har kodats utifrån ett kodschema. Därefter har alla ljudinslag kodats i ett Excel-dokument. De kodord som har använts har varit följande: socialt arbete, socialpolitik, hälso- och sjukvård, förebyggande arbete, handlingsutrymme, mänskliga rättigheter, delaktighet, stöd/ humanism, juridik, våld i nära relation, rekrytering, forskning, hemlöshet, etik samt dokumentation/digitalisering i socialt arbete. Dessa kodord har sedan blivit de teman som beskriver fokus i olika avsnitt. Om något varit oklart vid kodningen har lyssning av inslagen kunnat ske eftersom de finns tillgängliga på internet. Efter den statistiska bearbetningen har främst beskrivande statistik (frekvenser) använts i samband med analysen.

I analysen av materialet har det påträffats ett antal så kallade "röstbärare", det vill säga olika professionsföreträdare som medverkat i inslagen och har fătt sina röster 
hörda. De röstbärare som har identifierats var följande: socialarbetare, tjänstemän, forskare, läkare, representant från civilsamhälle, patient, anhöriga, facklig företrädare, politisk företrädare, författare och diakon.

Podcasterna är producerade och publicerade på internet och kan ses som offentligt material. Det är framför allt professionsfrågor och frågor på organisationsnivå, det vill säga samhällsnivå som har fokuserats i studien. Med anledning av att materialet består av en professions- och en myndighetspodcast har igen etisk prövning av studien genomförts. Däremot har Vetenskapsrådets principer för forskningsetik följts (Vetenskapsrådet, 2017). I materialet förekommer enskilda klienter och närstående som deltagit i podcaster, men dessa inslag har inte närmare undersökts med hänsyn till forskningsetiska aspekter (Vetenskapsrådet, 2017).

I figur 1 åskådliggörs produktionen av podcastinslag under perioden 2016-2019. Podcasten På djupet - en podd från Socialstyrelsen hade flest inslag under den studerade perioden (64 inslag) jämfört med Socialtjänstpodden som hade producerat 48 avsnitt.

Figur 1. Podcaster i en professionspodcast och en myndighetspodcast. Det empiriska materialet och dess fördelning under åren 2016-2019 ( $\mathrm{n}=112)$. Absoluta tal.

120

100

80

60

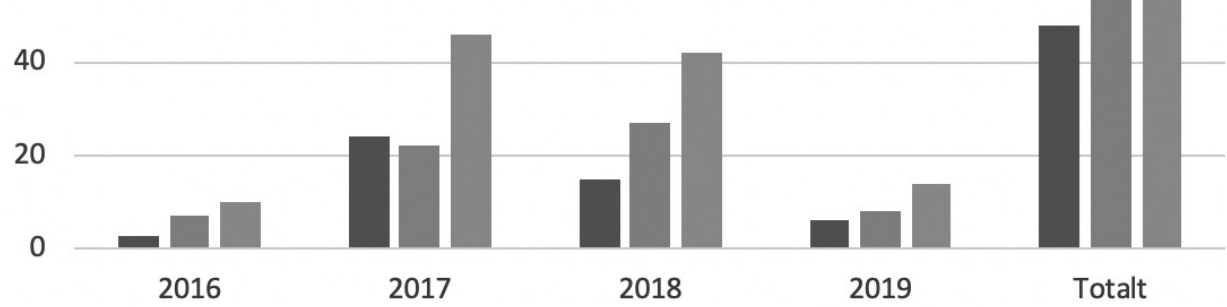

— Socialtjänstpodden — "På djupet"-podd — Totalt 


\section{Resultat}

I följande avsnitt presenteras studiens huvudresultat. Redovisningen sker utifrån de olika teman som har påträffats i materialet och de röster som hörts i de båda podcasterna.

\section{Teman och röster}

I Socialtjänstpodden var det största delen kvinnor som medverkade (72,9 procent) medan det i Socialstyrelsens myndighetspodcast i störst utsträckning medverkade både män och kvinnor i varje inslag (53,1 procent). Totalt medverkade 169 personer i de båda podcasterna under undersökningsperioden. 122 av dem medverkade i På djupet - en podd från Socialstyrelsen. Den hade även karaktären av att innehålla mer gruppdiskussioner där flera olika aktörer medverkade. Därmed kan den beskrivas som mer interaktiv till sin karaktär och genom att det deltog så pass många aktörer i de olika debatterna gavs det även möjlighet för både variation och bredd på diskussionerna.

I båda podcasterna var det flest tjänstemän, forskare och läkare som kom till tals i de olika programinslagen. Endast tio yrkesverksamma socialarbetare kunde göra sina röster hörda i dem vilket motsvarar 5,9 procent. Studien visar också att det är relativt ovanligt att andra professionsföreträdare i olika samverkansprofessioner till socialt arbete som till exempel sjuksköterskor och poliser medverkar i de olika programmen. Undersökningen visar att politikernas närvaro och deltagande i de båda podcasterna är mycket lågt, vilket är intressant med tanke på den politiska dimensionen i socialpolitik och inom hälso- och sjukvården. Läkare och tjänstemän har medverkat i större utsträckning och fått sina röster mest hörda i $P a ̊$ djupet - en podd från Socialstyrelsen. Huvudresultatet i studien visar att trots att möjligheterna finns att muntligt delta i debatter och diskussioner i socialt arbete och socialpolitik i de båda podcasterna, så har inte socialarbetarna tagit den möjligheten att göra sina röster hörda i någon större utsträckning. Resultatet är anmärkningsvärt av främst två skäl. För det första är socialarbetare en mycket viktig och tung aktör när det handlar om att dela erfarenheter och kommentera kopplingar, friktioner och utmaningar mellan socialt arbete och socialpolitik. De har sin professionsutbildning, erfarenhet men även tysta kunskap som de kan använda för att dela insikterna med andra aktörer i samhällsdebatten. För det andra är resultatet anmärkningsvärt eftersom podcastens roll är att stimulera både samhällsdebatt om socialt arbete och socialpolitik utifrån muntligt berättande och muntliga debatter. Det var endast tio socialarbetare som medverkade i podcasterna under hela tidsperioden som studerades (se tabell 2). 
Tabell 2. Röster som blivit hörda (olika röstbärare) $\mathrm{i}$ en professionspodcast och myndighetspodcast i socialpolitik och socialt arbete fördelat på yrkes- och professionskategori $(n=112)$. Absoluta tal och procent.

\begin{tabular}{lccc}
$\begin{array}{l}\text { Representerade röstbärare i } \\
\text { podcast 2016-2019 }\end{array}$ & $\begin{array}{c}\text { Socialtjänst-podden } \\
\text { (Akademikerför- } \\
\text { bundet SSR) }\end{array}$ & $\begin{array}{c}\text { På djupet - en podd } \\
\text { från Socialstyrelsen } \\
\text { (Socialstyrelsen) }\end{array}$ & $\begin{array}{c}\text { Totalt antal } \\
\text { röstbärare }\end{array}$ \\
\hline $\begin{array}{l}\text { Tjänsteman, utredare } \\
\text { Forskare }\end{array}$ & $14(29,8)$ & $56(46,0)$ & $70(41,4)$ \\
Läkare & 0 & $12(9,8)$ & $23(13,6)$ \\
$\begin{array}{l}\text { Representant i idéburen sektor, } \\
\text { civilsamhället }\end{array}$ & $5(10,6)$ & $20(16,4)$ & $20(11,8)$ \\
Socialarbetare & $4(8,3)$ & $8(6,5)$ & $13(7,7)$ \\
Chef inom socialtjänsten & $3(6,4)$ & $6(4,9)$ & $10(5,9)$ \\
Patientrepresentant & 0 & $5(4,1)$ & $8(4,7)$ \\
Facklig företrädare & $4(8,3)$ & $7(5,7)$ & $7(4,1)$ \\
Annan professionsutövare & $2(4,2)$ & $1(0,8)$ & $5(2,9)$ \\
Representant för anhöriga & 0 & $2(1,6)$ & $4(2,4)$ \\
Politiskt förtroendevalda & 0 & $3(2,4)$ & $3(1,8)$ \\
Författare & $2(4,2)$ & $2(1,6)$ & $2(1,2)$ \\
Programledare i podden & $1(2,1)$ & 0 & $2(1,2)$ \\
Diakon & $1(2,1)$ & 0 & $1(0,6)$ \\
Totalt & 47 & 0 & $1(0,6)$ \\
\hline
\end{tabular}

Studien visar att frågor om socialt arbete och socialpolitik är mest framträdande i professionspodcasten medan hälso- och sjukvårdsfrågorna varit mest framträdande i På djupet - en podd från Socialstyrelsen. Ett anmärkningsvärt resultat är också att det var flera medverkande som representerade civilsamhället. De fick sina röster hörda i större utsträckning än socialarbetarna. Ett intressant resultat i studien var att var fjärde podcastinslag i På djupet - en podd från Socialstyrelsen behandlade socialt arbete och socialpolitik och att 18,7 procent av samtliga inslag inrymde både frågor inom socialt arbete och hälso- och sjukvård. Men som huvudresultatet visar i studien, är det intressant att det är så få socialarbetare som deltagit i debatterna och diskussionerna om socialt arbete och socialpolitik (se tabell 3). 
Tabell 3. Huvudfokus i en professionspodcast och myndighetspodcast. Absoluta tal och procent.

\begin{tabular}{lccc} 
& $\begin{array}{c}\text { Socialtjänstpodden } \\
\text { (Akademikerförbundet } \\
\text { SSR) }(\mathbf{n}=\mathbf{4 8})\end{array}$ & $\begin{array}{c}\text { På djupet - en podd } \\
\text { från Socialstyrelsen } \\
\text { (Social-styrelsen) } \\
(\mathbf{n}=64)\end{array}$ & $\begin{array}{c}\text { Totalt antal } \\
\text { (n = 112) }\end{array}$ \\
\hline $\begin{array}{l}\text { Socialpolitik och socialt } \\
\text { arbete }\end{array}$ & $42(87,5)$ & $16(25,0)$ & $58(51,8)$ \\
$\begin{array}{l}\text { Hälso- och sjukvårdsfrågor } \\
\begin{array}{l}\text { Både socialpolitik, socialt } \\
\text { arbete och hälso- och } \\
\text { sjukvårdsfrågor }\end{array}\end{array}$ & $6(12,5)$ & $36(56,2)$ & $42(37,5)$ \\
\begin{tabular}{l} 
Totalt \\
\hline
\end{tabular} & 0 & $12(18,7)$ & $36(32,1)$ \\
\hline
\end{tabular}

I tabell 4 redovisas studiens huvudresultat utifrån de olika teman som har identifierats $\mathrm{i}$ analysen av samtliga programinslag. Totalt framkom tretton teman: 1) hälso- sjukvårdsfrågor, 2) förebyggande arbete, 3) handlingsutrymme, 4) mänskliga rättigheter, 5) delaktighet, 6) stöd/humanism, 7) juridik, 8) våld i nära relation, 9) rekrytering, 10) forskning, 11) hemlöshet, 12) etik samt 13) dokumentation/digitalisering i socialt arbete. 
Tabell 4. Identifierade teman i en professionspodcast och en myndighetspodcast om socialt arbete och socialpolitik. Absoluta tal och procent.

\begin{tabular}{|c|c|c|c|}
\hline Teman i podcasten & $\begin{array}{c}\text { Socialtjänstpodden } \\
\text { (Akademikerförbundet } \\
\text { SSR) }(\mathrm{n}=48)\end{array}$ & $\begin{array}{l}\text { På djupet - en podd } \\
\text { från Socialstyrelsen } \\
\text { (Socialstyrelsen) } \\
(n=64)\end{array}$ & $\begin{array}{c}\text { Totalt antal } \\
(\mathrm{n}=112)\end{array}$ \\
\hline Hälso- och sjukvård & 0 & $37(57,8)$ & $37(33,0)$ \\
\hline $\begin{array}{l}\text { Förebyggande arbete och } \\
\text { insatser }\end{array}$ & $13(27,1)$ & $16(25,0)$ & $29(25,9)$ \\
\hline $\begin{array}{l}\text { Socialarbetares handlings- } \\
\text { utrymme }\end{array}$ & $10(20,8)$ & 0 & $10(8,9)$ \\
\hline Mänskliga rättigheter & $5(10,4)$ & $4(6,2)$ & $9(8,0)$ \\
\hline Delaktighet & $6(12,5)$ & 0 & $6(5,3)$ \\
\hline Mänskligt stöd, humanism & $2(4,2)$ & $3(4,7)$ & $5(4,4)$ \\
\hline Juridiska frågor & $3(6,2)$ & $1(1,6)$ & $4(3,6)$ \\
\hline $\begin{array}{l}\text { Stöd mot våld i nära } \\
\text { relation }\end{array}$ & $2(4,2)$ & $1(1,6)$ & $3(2,7)$ \\
\hline Rekrytering & $2(4,2)$ & 0 & $2(1,8)$ \\
\hline $\begin{array}{l}\text { Dokumentering och } \\
\text { digitalisering }\end{array}$ & $1(2,1)$ & $1(1,6)$ & $2(1,8)$ \\
\hline Forskning & $2(4,2)$ & 0 & $2(1,8)$ \\
\hline Hemlöshet & $1(2,1)$ & $1(1,6)$ & $2(1,8)$ \\
\hline Etiska frågor & $1(2,1)$ & 0 & $1(0,9)$ \\
\hline
\end{tabular}

Som tidigare konstaterats visar huvudresultatet att enskilda socialarbetare har en tämligen svag röst $\mathrm{i}$ de båda podcasterna genom att de inte finns representerade $\mathrm{i}$ någon större utsträckning. De deltar inte aktivt i radioinslagen med sina egna röster, insikter och praktiska kunskap. Däremot är myndighetsperspektivet väl tillvarataget genom att olika experter och utredare deltar i berättelser och diskussioner om olika policyförändringar, historik och tillstånd i välfärdssamhället. En intressant iakttagelse är att andra röstbärare från exempelvis civilsamhället tagit plats i debatten $i$ podcasterna.

Historiskt har de traditionella medierna betraktats som mäktiga sett ur politisk opinionsbildning (Asp, 1986). Socialarbetaren har goda möjligheter att aktivt delta i samhällsdebatten som samhällskritiker och använda både de traditionella medierna och de sociala medierna som kanaler och arenor för att artikulera brister, kritik, inter- 
ventionsåtgärder och så vidare. Podcaster i synnerhet kan vara exempel på sådana arenor. Socialarbetarna har goda möjligheter att debattera sociala frågor och problem på samhällsnivå och har därmed möjligheter att agera för att kunna göra skillnad. De båda podcaster som analyserats i artikeln skapar förutsättningar för att sätta agendan, det vill säga att socialarbetare kan lämna in förslag till programidéer och själva ta initiativ till påverkan och medverkan (Golding \& Middleton, 1982). Ett anmärkningsvärt resultat i undersökningen är därför att inte fler sådana initiativ har tagits av socialarbetarna själva. Det är ett spännande resultat. Studien visar att det producerats totalt 112 inslag i de båda podcasterna under perioden 2016-2019. Totalt har 169 personer (röstbärare) medverkat, varav endast tio personer utgörs av enskilda socialarbetare och deras praktiska kunskap. Samtliga programinslag har varit på svenska språket, vilket bidragit till att debatter och diskussioner har kunnat ha en begränsad spridning till de nordiska och skandinaviska länderna. Sociala medier har annars goda möjligheter att kunna sprida kunskap och kännedom om till exempel socialpolitik och hälso- och sjukvårdsfrågor mellan flera länder (Keir et al., 2018).

Studien visar också att det framför allt är två dominerande teman som framträder: hälso- och sjukvård samt förebyggande arbete och insatser. Exempel på frågor som debatterats inom det första temat har varit "organ- och vävnadsdonation", "välfärdsteknik och personer med nedsatt beslutsförmåga", "om vården i livets slutskede" och att "bedöma barns mognad för delaktighet". När det handlar om temat förebyggande arbete och insatser, har diskussioner kommit att handla främst om "inblick i utredning om äldreomsorg", "hur vi förebygger våld bland barn och unga", "hot och våld på jobbet; hur vi skapar tryggare arbetsplatser" samt "mot bättre arbetsmiljö i socialtjänsten".

Hälso- och sjukvårdstemat har uteslutande utspelat sig i Socialstyrelsens podcast där 57,8 procent av inslagen $(n=37)$ fokuserade på hälso- och sjukvårdsfrågor och olika perspektiv inom vården. Tidigare forskning har visat att användning av podcaster i den högre utbildningen bland annat inneburit att studenter upplevt att de fått mindre interaktion med läraren jämfört med vid traditionell undervisning (Gnaur \& Huttel, 2016). Det är också viktigt att vara medveten om hur samspelet sker mellan teknologi, innehåll och pedagogik i en podcast. I den här artikeln har fokus inte varit på att undersöka ett sådant samspel. Inte heller har syftet varit att studera hur de olika röstbärarna upplevt deltagandet, temana och diskussionerna. Det skulle mycket väl kunna vara en fråga för vidare forskning på området hur socialt arbete, socialpolitik och olika teman framträder och framför allt upplevs av både lyssnare och medverkande personer i inslagen. Att medverka i traditionella medier eller podcaster är en fråga om hur och på vilket sätt som en professionsföreträdare väljer att aktivt använda sig av rätten till kritikrätt och yttrandefrihet (Carlsson \& Weibull, 2017). Likaså har anställdas kritikrätt belysts i litteraturen (Fransson, 2013). 
Tidigare forskning har visat att socialarbetare i Sverige både historiskt och i vår egen samtid varit relativt återhållsamma och till och med tysta i den offentliga debatten om socialt arbete och socialpolitik (Lundälv, 2013; 2018; 2019). Rädslor och osäkerhet om den generella medierapporteringen om socialt arbete samt att möta journalister i samtal om professionsfrågor har även visat sig vara en problematik (Lundälv \& Moberg, 2006; Sjöström \& Öhman, 2018). De personer som medverkat i de olika avsnitten i podcasterna har hänvisat till olika dokument som bidragit till att stödja deras egen argumentation i debatterna. Det har handlat om dokument som till exempel nationella riktlinjer, artiklar, utredningar, rapporter, doktorsavhandlingar, statistik, lagar och regler. Undersökningen visar att det varit vanligast att deltagarna i Socialtjänstpodden hade olika dokument att hänvisa till, vilket skedde i hälften av avsnitten. I Socialstyrelsens podcast var det något färre (37,5 procent) som hänvisade till olika källor. I vart tredje programinslag i de båda podcasterna behandlades barnperspektivet och dess innebörd. I Socialtjänstpodden hade barnperspektivet debatterats 115 avsnitt (31,3 procent) medan perspektivet hade diskuterats i Socialstyrelsens podcast $i 21$ avsnitt ( 32,8 procent).

\section{Diskussion och slutsats}

Under senare år har det öppnats upp för flera olika professionsföreträdare att medverka i opinionsbildning och debatt i så kallade podcaster på internet. För socialarbetare finns det goda möjligheter att delta i flera olika. Det handlar om möjligheten att delta i både den nationella diskussionen i sociala frågor, mänskliga rättigheter och policyfrågor. Språk och kulturkompetens hos socialarbetare kommer i framtiden att kunna skapa nya förutsättningar och arenor $i$ aktuella frågor i socialt arbete och socialpolitik. Artikeln har presenterat så vitt är känt den första nationella studien om podcaster i socialt arbete och socialpolitik som fokuserat på ett professionsförbund och en statlig myndighets engagemang och produktion av podcaster. Artikeln har handlat om vilka röster som kommer till tals och vilka olika teman som kommit till uttryck i två podcaster som ges ut av ett professionsförbund (Akademikerförbundet SSR) och en statlig myndighet (Socialstyrelsen). I artikelns avslutande del diskuteras studiens resultat, det vill säga dess kunskapsbidrag, som är opinionsbildningens betydelse för socialpolitiken och där socialarbetare kan höja sin röst i debatten. Men det handlar även om hur de också på ett tydligare sätt kan positionera sig i viktiga och angelägna frågor om socialt arbete och socialpolitik. Studiens kunskapsbidrag har handlat om att synliggöra socialarbetarnas deltagande i samhällsdebatten när det ges möjlighet för muntlig debatt och berättartradition. Socialarbetare har mycket erfarenhet av att föra samtal och att lyssna i olika möten. Deras professionsutbildning men också deras tysta kunskap som de har förvärvat borde kunna skapa goda möjligheter att tala om 
och därigenom dela till andra. Det skulle i framtiden kunna främja en högre närvaro i samhällsdebatten. Att socialarbetarna inte delar med sig av sina erfarenheter och den praktiska kunskap som de har i offentlig debatt skulle kunna hänföras till den grundtanke som Polanyi beskrev under 1950-talet, nämligen att "vi kan veta mer än vi kan säga" (Polanyi, 2013, s. 27). Att en socialarbetare kan ta ton i debatten och höja sin röst skulle kunna innebära att vi kan få lyssna på nya dimensioner och perspektiv i socialpolitik som kanske inte har lyfts upp tidigare.

Att aktivt delta och medverka i olika podcaster i framtiden skulle kunna vara en värdefull kanal och arena för den enskilde socialarbetaren att både träna på och att utveckla sina färdigheter i muntlig debatt. Podcaster skulle kunna vara ett bra verktyg för socialarbetare att använda för att nå ut i den offentliga sfären och synliggöra de professionsfrågor, sociala frågor samt socialpolitiska frågor som hittills fått ett alltför begränsat utrymme eller blivit osynliggjorda. Men det här handlar om så mycket mer än att delta i en enskild podcast. Socialarbetares engagemang i samhällsdebatten är också något som är mycket vidare än så. De kan nå utsatta grupper och genom sina berättelser kan också de sociala problemen och till exempel bristerna i socialpolitiken synliggöras. På så vis kan de också bli tillgängliga för till exempel personer med olika funktionsnedsättningar, personer som har kognitiva svårigheter och alla dem som är försatta i politisk fattigdom i samhället. Med detta sagt kan socialarbetarna genom att delta i podcaster också kunna stärka funktionshinderperspektiv, mänskliga rättigheter och generellt sett bidra till en ökad folkbildning. En ökad medvetenhet hos socialarbetare om opinionsbildningens och folkbildningens betydelse skulle också på sikt kunna stärka den egna professionsutvecklingen. Även om tyst kunskap kan vara svår att förmedla, har socialarbetare genomgått högre utbildning och har mycket erfarenheter från det sociala arbetets fält. När barnkonventionen blir lag och när betydelsen av förebyggande arbete lyfts upp, exempelvis genom översynen av socialtjänstlagen, borde socialarbetarna kunna ta plats i debatten och använda sina röster betydligt mer än vad som är fallet i dag. De har goda möjligheter att kommentera och föreslå interventioner på samhällsnivå. Resultatet i den här studien har visat att det främst är hälso- och sjukvårdsfrågorna samt förebyggande arbete och insatser som kan ses som de allra mest brännande socialpolitiska frågorna i vår tid. Vilka erfarenheter har socialarbetare när det handlar om att möta barn och ungdomar med psykisk ohälsa? Vilka förebyggande åtgärder fungerar mest effektivt enligt socialarbetarna själva? Det är exempel på frågor som skulle kunna lyftas upp i samhällsdebatten. Andra socialpolitiska frågor som socialarbetarna kan engagera sig i skulle kunna handla om exempelvis ett digitalt utanförskap som innebär att det finns äldre människor som inte använder sig av internet över huvud taget samtidigt som det kan saknas möjligheter för unga personer med funktionsnedsättningar att använda podcaster på internet på grund av att de saknar förmåga till att hantera dator och sociala medier. 
Det är därför viktigt att också ställa frågan om vilka människor i samhället som kan lyssna på podcaster och vilka som saknar möjligheterna. Här skulle kunna finnas risk för att grupper blir exkluderade från att ta del av debatter och diskussioner. Mer kunskap behövs om sådana risker.

Studien har också visat på utbredningen av det dominerande temat (hälso- och sjukvård). Inom det temat borde fler socialarbetare (t.ex. kuratorer inom hälso- och sjukvården och i primärvården) kunna medverka med insikter och erfarenheter i en samhällskritisk debatt. För att stärka en diskussion och debatt kan det vara viktigt att stödja resonemang och argumentation med något hänvisande dokument. I analysen av de olika inslagen har så kallade hänvisande dokument påträffats i nästan hälften av inslagen (42,9 procent). Ett sådant dokument kan vara en utredning, rapport, nationella riktlinjer och så vidare. Ur ett trovärdighetsperspektiv är det angeläget samtidigt som lyssnare måste ha möjlighet att värdera och göra en källkritisk bedömning av argumentation och påståenden i en debatt. I tider då nyhetsmedierna (dagspressen) i de traditionella medierna minskat i Europa konstateras att användandet av sociala medier, särskilt hos unga människor, ökat allt mer i omfattning (Lie Paulsen, 2018).

Det finns flera utmaningar när det handlar om att föra den muntliga berättartraditionen vidare om socialt arbete och socialpolitik, bland annat i de sociala medierna. En utmaning är hur fler socialarbetare ska kunna engageras i debatter och diskussioner om sociala välfärdsfrågor och socialpolitik. Genom att professionsförbund och myndigheter står som utgivare av podcaster skulle det kunna upplevas som avdramatiserande jämfört med om en socialarbetare skulle medverka $i$ en direktsänd radiointervju (där tröskeln för medverkan ibland kan vara hög) eller bli intervjuad av en journalist vid en dagstidning. Men det finns också fler utmaningar i produktionen av podcaster. Som nämndes i artikelns inledning medverkade professor Fiona Williams vid en inspelning av en videopodcast vid University of Oxford. Genom att hålla anföranden och medverka i offentliga debatter kan forskare i socialpolitik och socialt arbete även stärka sitt engagemang och åtagande för den tredje uppgiften. I en vetenskaplig artikel publicerad i tidskriften Social Policy \& Administration reflekterar Fiona Williams ur ett socialpolitiskt långtidsperspektiv när hon skådar olika "vågor" av kritiskt tänkande. Hon avslutar sin artikel med orden: "Bringing all these together reflects the many of the priorities for the waves of critical thinking about social policy over the past 40 years which this article has discussed. It provides the seven Rs as a repertoire of critical demands: Redistribution, Recognition, Representation, Rights, Regulation, Relationality and Resource-awareness" (Williams, 2016, s. 642). De områden som Williams pekar ut som centrala skulle mycket väl kunna utgöra grunden och utgångspunkterna för en kritisk diskussion om socialt arbete och socialpolitik i framtida podcaster. De här områdena skulle även kunna användas för vidare forskning och analyser av podcaster i socialpolitik. En annan utmaning med 
podcaster i socialt arbete och socialpolitik där olika professionsföreträdare medverkar kan vara att programinslagen skulle kunna användas som material och underlag $i$ socionomutbildningen. I den vetenskapliga diskussionen har det pedagogiska värdet av podcaster $i$ den högre utbildningen särskilt betonats inom utbildningen i socialt arbete (Robbins \& Singer, 2014).

Att överblicka socialpolitiska trender och skåda utvecklingen över tid fordrar både teoretisk och praktisk kunskap. Kanske är det så att många socialarbetare ännu inte har kommit till insikt om vilka unika möjligheter som de sociala medierna och podcaster i synnerhet kan berika socialt arbete och socialpolitik med. När socialarbetarna inser att de kan använda sin yttrandefrihet och själva vara med och sätta agendan för socialpolitiska debatter och podcaster, kommer också det offentliga demokratiska samtalet att kunna stärkas och utvecklas. Det är naturligtvis svårt att säga något generellt om hur utvecklingen av poddradio och olika podcaster kommer att se ut i Sverige de närmaste åren. Den här studien har kunnat visa att intresset för podcaster hos ett professionsförbund och en myndighet varit stort och att ett relativt stort antal programinslag producerats. Samtidigt som andra professionsförbund, myndigheter och organisationer också producerar podcaster, kommer det att ställa ökade krav på delaktighet för socialarbetare i skilda sammanhang. Podcaster i socialt arbete och socialpolitik skulle även kunna användas som verktyg i socionomutbildningen. I litteraturen har de beskrivits som ett inkluderande arbetssätt även ur ett pedagogiskt perspektiv. Ett skäl kan vara att de är ett inkluderande arbetssätt både hos elever i skolan och studenter i den högre utbildningen (Nyman \& Senneryd, 2015; Gnaur \& Huttel, 2016). Genom podcaster kan värdefulla insikter och erfarenheter delas mellan människor i liknande situation men även till journalister i de traditionella medierna (press, radio, tv och internetredaktioner). Genom att till exempel unga människor (studerande) får lyssna på andra podcaster kan de utveckla sina sinnen och insikter för att sedan kunna producera egna. I den högre utbildningen i olika ämnen används också podcaster som verktyg. Det innebär att allt fler människor får vana i att använda sig av den typen av verktyg och kanal i de sociala medierna. Den tysta kunskapen skulle då även kunna delas och användas när socialarbetarna i framtiden höjer sin röst i en socialpolitisk fråga. Vi talar här om att socialpolitiken kan bli omdebatterad och att socialarbetare blir mer involverade i välfärdens utveckling.

\section{Deklaration}

Artikelförfattaren till artikeln deltar i ett inslag i Socialtjänstpodden under 2019 men har ingen annan koppling till de båda podcaster som ingår i studien. 


\section{Referenser}

Akademikerförbundet SSR. (2019) Socialtjänstpodden.

[https://akademssr.se/opinion/vara-podcasts/socialtjanstpodden Hämtat: 2019-05-06].

Asp, K. (1986) Mäktiga massmedier. Studier i politisk opinionsbildning. Stockholm: Akademilitteratur.

Baum, M.A. \& Potter, P.B.K. (2019) Media, public opinion, and foreign policy in the age of social media. The Journal of Politics, 81(2): 747-756.

Blomberg, H. (red.) (2004) Sociala problem och socialpolitik i massmedier. Lund: Studentlitteratur.

Carlsson, U. \& Weibull, L. (2017) Yttrandefriheten i dagens mediekultur. En studie av medborgarnas uppfattning om yttrandefrihetens gränser. Nordicom. SOM-institutet. Göteborg: Göteborgs universitet.

Cartney, P. (2013) Podcasting in an age of austerity. A way of both enhancing student learning and reducing staffing costs? British Journal of Social Work, 43(3): 446-466.

Elgemyr, G. (2005) Får jag be om en kommentar? Yttrandefriheten i svensk radio 1925-1960. Nr 20 i en serie skrifter utgivna av Stiftelsen Etermedierna i Sverige. Stockholm: Prisma.

Enbom, J., Sjöström, S. \& Öhman, A. (2014) Institutionella villkor för mediehantering. En jämförande kartläggning mellan socialtjänst, skola och polis. Socialvetenskaplig tidskrift, 21(2): $105-126$.

Fjellman, E., Gustafsson N. \& Rosén Sundström, M. (2018) Ungas politiska (icke-)deltagande på sociala medier. Hellre offline? Sociologisk Forskning, 55(2-3): 293-316.

Fransson, S. (2013) Yttrandefrihet och whistleblowing. Om gränserna för anställdas kritikrätt. Stockholm: Premiss.

Fronek, P., Boddy, J., Chenoweth, L. \& Clark, J. (2016) A report on the use of open access podcasting in the promotion of social work. Australian Social Work, 69(1): 105-114.

Gnaur, D. \& Huttel, H. (2016) Podcasting for teaching and learning in higher education. 1 uppl.Aalborg University. Aalborg: Aalborg Universitetsforlag. Higher Education Practices Series, No. 2.

Golding, P. \& Middleton, S. (1982) Images of welfare. Press and public attitudes to poverty. Oxford: Robertson.

Goldkind, L., Wolf, L. \& Freddolino, P.P. (2018) Digital social work. Tools for practice with individuals, organizations, and communities. New York: Oxford University Press.

Jenkins, H., Ford, S. \& Green, J. (2014) Spridbar media. Att skapa värde och mening $i$ en nätverkad kultur. Göteborg: Daidalos.

Keir, A., Bamat, N., Patel, R.M, Elkhateeb, O. \& Roland, D. (2018) Utilising social media to educate and inform healthcare professionals, policy-makers and the broader community in evidence-based healthcare. BMJ-Evidence-Based Medicine, 1-3.

Krippendorff, K. (2019) Content analysis.: An introduction to its methodology. Fourth edition. Los Angeles: SAGE.

Lie Paulsen, M. (2018) Local newspapers, facebook and local civic engagement. A study of media use in two Norwegian communities. Nordicom Review, 39(2): 49-62.

Lundälv, J. (2013) Pennfäktaren. Socialt arbete och opinionsbildning. 1 uppl. Gävle: Meyers förlag.

Lundälv, J. (2015) Blogga tryggt. Nya medier i tjänsten. 1 uppl. Lund: Studentlitteratur.

Lundälv, J. (2018) Debattlustans röster. Samhällskritik $i$ socialpolitik och socialt arbete. 1 uppl. Stockholm: Premiss förlag.

Lundälv, J. (2019) The challenges of writing opinion pieces in social work. A national online survey of Swedish social workers' experiences of influencing public opinion. British Journal of Social Work, 49(6): 1395-1414. 


\section{Socialvetenskaplig tidskrift 2019:3-4}

Lundälv, J. \& Lindqvist, R. (2013) Aktivering och anställningsbarhet eller modernt arbetstvång? En analys av fas 3 i svensk dagspress. Arbetsmarknad \& Arbetsliv, 19(3): 9-23.

Lundälv, J. \& Moberg, U-C. (2006) Mediehandbok för socialarbetare. Gävle: Meyers förlag.

McCombs, M. \& Shaw, D. (1972) The agenda-setting function of mass media. Public Opinion Quarterly, 36(2): 176.

Nordicom. (2017) Radiolyssnandet i Norden 2016. Nordicom - Nordisk Informationscenter för Medie- och Kommunikationsforskning. Göteborg: Göteborgs universitet.

Nyman, M. \& Senneryd, K. (2015) Podcast i undervisningen skapar motiverade elever. Ett inkluderande arbetssätt där elever lär av varandra vid inspelandet av strukturerade samtal. Skolportens numrerade artikelserie för utvecklingsarbete i skolan. 10/2015. Ifous, Skolporten.

Oakley, A., Popay, J. \& Williams, F. (1999) Welfare research. A critical review. London: UCL Press.

Plantin, J.-C. \& Punathambekar, A. (2018) Digital media infrastructures. Pipes, platforms, and politics. LSE Research Online. Journal of Media, Culture \& Society, 41(2): 163-174.

Polanyi, M. (2013) Den tysta dimensionen. Göteborg: Bokförlaget Daidalos AB.

Robbins, S.P. \& Singer, J.B. (2014) From the editor. The medium is the message. Integrating social media and social work education. Journal of Social Work Education, 50(3): 387-390.

Scaramuzzino, G. \& Meeuwisse, A. (2019) Socialarbetares protester genom nätverk på sociala medier. Socionomens forskningssupplement, 45(1): 4-17.

Sjöström, S. \& Öhman, A. (2018) What if an investigative journalist calls? Media relations in social work. British Journal of Social Work, 48(7): 2077-2095.

Socialstyrelsen. (2019) På djupet - En podd från Socialstyrelsen.

[https://www.socialstyrelsen.se/padjupet-podd/Files/index.html Hämtat: 2019-05-06].

Strömbäck, J. (2009) Makt, medier och samhälle. En introduktion till politisk kommunikation. 1 uppl. Stockholm: SNS förlag.

Swärd, H. (red). (2017) Den kantstötta välfärden. 1 uppl. Lund: Studentlitteratur.

Swärd, H. (red). (2018) Bedöma och åtgärda fattigdom. Om välfärdens skiljelinjer och samhällets yttersta skyddsnät. 1 uppl. Lund: Studentlitteratur.

Swärd, H. \& Edebalk, P.G. (red). (2017) Socialt arbete och socialpolitik. Om Centralförbundet för socialt arbete och dess betydelse. 1 uppl. Lund: Studentlitteratur.

Thompson, J.B. (2001) Medierna och moderniteten. Göteborg: Bokförlaget Daidalos AB.

Tiitinen, L. (2019) Kamppailu. Sananvapaudesta. Sosiaalialan ammattilaisen tominta ja valtasuhteet mediavaikuttmisen kentällä (Struggle for free speech. Engagement in media advocacy and the associated power relations as experienced by social work professionals). Väitöskirja. Acta Electronica Universitatis Lapponiensis 259. Rovaniemi: Lapin Yliopisto, University of Lapland.

Weibull, L. \& Wadbring, I. (2014) Massmedier. Nya villkor för press, tv och radio i det digitala medielandskapet. 11 helt omarb. uppl. Stockholm: Ekerlid.

Vetenskapsrådet. (2017) Godforskningssed. Stockholm: Vetenskapsrådet.

Williams, D.L, Crittenden, V.L, Keo, T. \& McCarty, P. (2012) The use of social media. An exploratory study of usage among digital natives. Journal of Public Affairs, 12(2): 127-136.

Williams, F. (1989) Social policy. A critical introduction. Issues of race, gender and class. Cambridge: Polity Press.

Williams, F. (1999) Good-enough principles for welfare. Journal of Social Policy, 28(4): 667-687.

Williams, F. (2016) Critical thinking in social policy. The challenges of past, present and future. Social Policy \& Administration, 50(6): 628-647.

Williams, F. (2018) What next for social policy? Podcast, University of Oxford. November 9. [https://podcasts.ox.ac.uk/what-next-social-policy Hämtat: 2018-11-09] 